\title{
Investigation of Causes of Delay in High Rise Building Project and Remedial Measures Case Study-Pune
}

\author{
${ }^{*}$ Kushal K.Panchariya ${ }^{1}$, Prof. P. P. Bhangale ${ }^{2}$ \\ ${ }^{1} P G$ Scholar, Department of Civil Engineering, SSGBCOET, Bhusawal, Maharashtra,India ${ }^{l}$ \\ ${ }^{2}$ HOD, Department of Civil Engineering, SSGBCOET, Bhusawal, Maharashtra, India ${ }^{2}$ \\ Corresponding Author: KushalK.Panchariya
}

\begin{abstract}
At present, the approval processes involved in construction projects is complex all over country While undertaking construction projects like residential, commercial or industrial etc., it has been observed that obtaining clearances for the Building Projects has become cumbersome and lengthy. Overthepastdecade it has been observing that huge population enters into big cities like Pune for bread and butter, so there is tremendous demand for housing. This demand is fulfilled by developer, builder. But due to less availability of land, vertical construction is most demanding in the form of high rise buildings. But at the same time some sensitive issues like getting approvals on time and ground facts like delays in getting approvals need to be focus so customer will get its possession in time from developer and at the same time builder shall not incur losses due to delay in sanctioning of approvals as it plays magnificent role.
\end{abstract}

Keywords: Approval procedures for high rise buildings, Delays in high rise building construction, NOC for building projects in Pune.

Date of Submission: 13-07-2017

Date of acceptance: 15-07-2017

\section{INTRODUCTION}

Pune has the perfect record of highest growth within a span of 20 Years. Pune has the highest number of software companies in India. Pune has the highest density of traffic in India. Pune has 42 engineering colleges, which is highest in the world in a given city. Pune is the only city in the world to have commercial and defense Airport operating from the same strip. Pune has highest number of public sector and government Organizations in India. Pune City Corporation was facing challenges like Haphazard Development, Lack of proper monitoring system leading to inefficiency, Eroding accountability due to delay in permissions. Declining public image due to increasing gap between service delivery and public expectation and Non uniformity in the interpretation of DC-rules. As per the MR\&TP Act 1966 Pune Municipal Corporation is the legitimate authority to prepare land use plan and take care of plan implementation, control the development and manage the growth of city. The main goal was ensuring a planned development; promoting healthy urban environment, reducing congestion and crowd, preventing development of conflicting-land use etc.

\section{LITERATURE SURVEY}

1. K. B. Vaghani, Dr. N. C. Shah and Dr. Krupesh A Chauhan,Impact of Building Byelaws on Housing: A Comparative Study of Development Control Rules of Jaipur and
Pune,Institute of Town Planners, India Journal 7 - 2, 34 - 40, April - June 2010Housing is the prime necessity of human beings. Government has made many policies to encourage the housing activity. Building Byelaws affect housing activities very significant in terms of its utilization and cost.Building Byelaws control the numbers of dwelling units, in some cases, that can be accommodated in a given parcel of land by implementing the essential clauses such as Built Up Area, FSI/FAR, Maximum Building Height, Margins to be kept open in front and around the buildings, etc. The impact of all these clauses varies to the extent of 200 percent in case of Jaipur and Pune city. Attempt has been made in this paper to reveal the impact of Byelaws on housing. Comparative study has been done for Jaipur and Pune cities for five building forms and impact has been revealed.

2. Ministry of Housing and Urban Poverty Alleviation (MoHUPA), Report of The Committee of Streamlining Approval Procedures for Real Estate Projects In India, Key Recommendations, Volume I,12 september 2012.-In India, the need and demand for both housing and infrastructure are enormous. With the population crossing 1.20 
billion in 2011, the magnitude of housing shortage at the end of the $10^{\text {th }}$ Plan was around 24.7 million units for 67.4 million households. It is estimated that $99 \%$ of this shortage pertains to Economic Weaker Sections (EWS) and Low Income Group (LIG) categories. During the 11th Plan, the total housing requirement (including backlog) will be around 26.53 million units for 75.01 million households. At present, nearly $70 \%$ of the country's population lives in rural areas. But with Foreign Direct Investment (FDI) pouring in the country, urbanisation is spreading its roots in India like never before. It is estimated that by $2030,40 \%$ of the country's population will be living in the urban area. With urbanisation and growth of cities, there is need and urgency for better governance. Even though, Real estate in India is the 2nd most important sector after Agriculture, having secondary and tertiary linkages in terms of employment, GDP growth etc

3. Town and Country planning organization, Government of India, Ministry of Urban Development, Streamliningprocedures for clearance of building projects, September 2010-

In India, the need and demand for both housing and infrastructure are enormous. With the population crossing 1027 million in 2001, the magnitude of housing shortage at the end of the 10th Plan was around 24.7 million units for 67.4 millionhouseholds. Further, it was estimated that $99 \%$ of this shortage pertains to EWS \&LIG categories. During the 11th Plan, it is estimated that the total housing requirement (including backlog) will be to the tune of 26.53 million units for 75.01 million households.The powers to frame Building Regulations/Bye-

Laws vest with the Urban LocalBody or Urban Development Authority of State Government under statutory provisions. Building Regulations/Bye laws are a set of laws and procedures that all building practitioners, such as builders, architects, design consultants, and contractors, have to abide by, when engaging in the construction of a new building or in the modification of an existing building with structural changes. The core issue of

Building Regulations is to obtain number of clearances related to building projects.

4. Report of the Committee on Streamlining Approval Procedures for Real Estate Projects in India,Key recommendations, Volume-I, 12 September 2012

One of the foremost demands of the Real estate industry across the Country is to facilitate fasttrackand transparent system of project approval procedures. The current procedures followed bylocal
Governments, starting from receiving the application to giving the completion certificate, are ridden with a lack of clarity or structure, complexity of design and operation, inefficiency and uncertainty and time/resource consumption. Therefore, it is important to study the procedures that are leading to inefficient outcomes and that are giving scope for either apathy towards developers or corruption. Evidence suggests that the process of approval involving statutory authorities of Central Govt, State Govt. and Local Municipal Corporations takes 90 to 600 days. McKinsey estimates that the delay in project approvals certainly has a huge bearing on the project cost to the tune of 40 percent. The single intervention in approval process that can make a huge difference was equivocally said to be e-based single window mechanism to enable coordination among the multiple authorities dealing with various permissions/approvals.

\section{TYPES OF APPROVALS}

1.Overview

Before constructing any building in a plot by a plot owner, he/she needs to apply for a land use clearance to check its conformity with the master plan's land use proposals. If the applied land use confirm the master plan's proposal, the plot owners gets the land use clearance certificate and apply for the planningpermission for constructing building with detail plan and design of the site and building. This process is same for residential, commercial and industrial plot. Earlier getting a land use-clearance certificate and building permission was much more complicated. Pune City Corporation was facing challenges like Haphazard Development, Lack of proper monitoring system leading to inefficiency, Eroding accountability due to delay in permissions. Declining public image due to increasing gap between service delivery and public expectation and Non uniformity in the interpretation of DC-rules.

Basically there are 11 parts including sequence of approvals as well as requirements which is to be fulfilled by developers or builders while construction of high rise buildings in case of Pune city is as follows:

1. Administration

2. General land development requirements

3. Land use classification and permissible uses

4. General building requirements-setback, marginal distance, height and FSI

5. Requirements of parts of buildings

6. Parking loading and unloading spaces

7. Acquisition/development of reserved sites in development plan

8. Higher FSI in certain categories in noncongested areas 
9. Structural safety, Water supply, Drainage and Sanitary requirements, Outdoor display structures.

10. Special provisions in certain buildings

11. Special schemes/Activities

Administration consists of following process which involves all forms of application from beginning to end phase:

Application form for construction of building or layout of building or group housing, application form for sub-division of land as plotted layout, form for supervision, qualifications and duties of licensed technical personnel, form for sanction of building permit/commencement certificate, form for tentative approval for demarcation of land, form for final approval of building permit, form for refusal of sanction to building permit/commencement certificate, form for refusal of sanction to land sub division/layout, form for intimation of completion of work up to plinth level, form for approval /disapproval of development workup to plinth level, form for completion certificate, form for occupancy certificate, form for refusal of occupancy certificate, form for part occupancy certificate.

Meanwhile, different approvals are needed as follows:

1. Ownership Certificate/Extract-

2. Building Layout Approval

3. Non-Agriculture Permission

4. Obtain "no-objection certificate" NOC from the Tree Authority (Municipal)

5.Obtain NOC from the Storm Water and Drain Department (Municipal)

6. Obtain NOC from the Sewerage Department (Municipal)

7.Obtain NOC from the Electric Department (Municipal)

8. Obtain a "no-objection certificate" NOC from the Traffic and Coordination Department(Municipal)

9. Obtain a Provisional NOC from the divisional Fire Officer (Municipal)

10. Environment Clearance

11. Ancient Monument Approval:

12.Consent to establishment and operate:

13. NOC from Airport Authority of India

14.Bore well Registration Certificate: (Outside Municipal Limit)

15. Permission for Excavation / Royalty payment

16. Other Common Facilities Approval: (Internal Infrastructure services)

17. Road Access Highway / Expressway:

18. Lift Escalator Installation Approval (PWD / CPWD)

19. Electric substation NOC For all substation Transformers in building (Electric Service Provider)
20.Obtain permanent water connection (with inspection) (Municipal)

21.Obtain permanent sewerage connection (Municipal)

\section{Reasons for delays due to approvals and NOC Ownership certificate/extract-}

This certificate is very important because name of owner is mentioned on it directly as well as any transferofproperty. When buying a property, due diligence is essential and you have to verify a lot of important property documents. Patta or mutation or Khata is one such important property document.Mutation is the change of title ownership from one person to another when the property is sold or transferred. By mutating a property, the new owner gets the title of the property recorded on his/her name in the land revenue department and the government is able to charge property tax from the rightful owner.One needs to get mutation done and get the new owner details updated in the revenue records maintained by civic bodies like Municipalities, Panchayats or Municipal Corporations. Once the property is registered in Subregistrar office, the buyer of the property has to get the title of the property updated in his/her name in the local revenue office. This is known as mutation. Once the property is updated in the revenue records, henceforth the new owner has to pay the applicable taxes to the civic body (like property tax,development charges.

NA permission-Following permissions and NoCs are required before granting NA permission including Tehsildar/Patwari, Maharashtra State Electricity Distribution Company Ltd (MSEDCL), SubDivisional Officer (SDO), Land Acquisition Officer (LAO), Resettlement Office, Public Works Department/ National Highway, Mining, Public Health Officer, Town Planning, Gram Panchayat and Urban Land Ceiling (ULC).

-Non-agriculture permission also required for land within Municipal Limits.

For Consent to establish and operate-Ministry of Environment has authorized Pollution Control Board (PCB) to monitor the environmentrelated compliance by the developer. This proposal is sent to Mumbai headquarter for approval then back to Pune corporation causes delay.

\section{Environment Clearance-}

-MOEF should clear the Zonal Development Plan, no approvals for individual projects

-Local Development Authority be entrusted the task of environment clearance

-Projects above 50,000 sq. mts built up area should only be eligible for environment clearance as after 
this limit environment may affect if measures are not taken.

-The state must set up a separate committee for according environment clearance to the construction sector due to the large number of projects happening in the state. Because presently there is only one state environment appraisal committee which takes care of all residential, commercial and industrial projects in the state. Having a specialized environment appraisal committee.

NOC from Airport Authority of India-High rise buildings above $100 \mathrm{~m}$ only requires this type of noc but the measure issue is that proposal sent to Mumbai, Delhi, Bhopal, Kolkata offices of Directorate General of Civil Aviation and reverse in order again. So this approval/NOC process is time consuming.The NOC from Airports Authority of India takes about 12 months to 2 years and could be relaxed selectively.Actually NOC from AAI should be linked to the Development Plan(DP). In other words DP should clearly allot areas which would require AAI clearance for projects, area outside this need not require AAI NOC and be free to develop as per the DPand TP scheme.

Ancient Monument Approval: The NOC from Archeological Survey of India is a slow process. It has been observed that all the buildings under the purview of ASI are treated with equal importance and the conditions laid down for development of realestate projects near them are also same for all monuments. The approval from ASI nearly takes about a year which is a very long time and literally slows down the whole development process.

\section{RECOMMENDATIONS}

1. Adopt a single window for clearance or facilitation of approvals-

The concept of a 'Single window' or 'One stop shop' is widely recognized as an effective effective tool to ensure speedy approvals. This has been used very successfully in India by the Department of Industrial Policy and Promotion, to improve the investment climate by improving the 'ease of doing business' in the country.

'Single window' can be implemented in various forms -

i. Appointing nodal agency or authorized officer

ii. Enacting 'single window' legislation that extends the nodal agency concept to include other enabling mechanisms such as empowered committees

iii. By connecting all/select departments by a technology interface, which acts like a single window.

2. Invest in adopting robust technology platform(s) at state level- all central, state and local government departments are connected through a strong technology backbone and all project applications and approvals are processed online. It is imperative to leverage technology to expedite approvals and added advantages such as

i. Remove paperwork and physical visits

ii. Improve transparency and accountability through regular reporting \& escalation mechanism

iii. Remove ambiguity and discretion by auto detection / verification where possible

iv. Minimize corrupt practices by e-payment facilities

\section{Consolidate and streamline building laws at} national and state level-

In order to remove overlapping or contradicting building bye laws, to remove ambiguity it is imperative that the state building laws are consolidated in a simpler format and streamlined according to the current needs.

i. Update provisions of NBC which are outdated or impractical in ensuring speedy approvals, without compromising standards

ii. Aligning the chapter on 'sustainability' to be in line with the provisions of 'environment law' or requirements for 'environment clearances'

4. Clear processes and timelines for greater clarity and predictability-

One of the main issues in real estate project approvals is the uncertainty and ambiguity with constantly varying requirements of documents and interdependencies on approvals /NOCs. This leads to applicants / developers approaching various departments multiple times without understanding complete requirements or processes.

5. Examine approval processes that can be removed, simplified or delegated-Approval of real estate projects is a complex process involving many departments across central,state and local governments. The surplus of stateand local laws regulating real estate development makes it difficult for the Committee to identify exact type of approvals/activities

i. Remove duplicity or unnecessary approvals activities/documentation - e.g dual process of getting conversion of land use approval from revenue department as well as town planning /local dept. may be done away with.

ii. Simplify approval process by clearly stating applicable rules and restrictions - there may be opportunities to cut down the need for NOC from different authoritiese.gNational Monuments Authority, Airport Authority of 
India, if the restricted areas are made available in public domain beforehand.

iii. Identify activities / services that can be automated -e.g building plans, payments.

iv. Identify activities / approvals that may be delegated - eg planning approvals (zoning plan or change in land use) can be delegated to local bodies when they are adequately trained.

6.Expedite decision making and clearance of long pending applications-

i. State governments to consider constituting empowered committees at state level, to take a decision on all pending applications, in order to grant approvals or intimation of disapproval.

ii. State governments should encourage to use the concept of 'Deemed approval' after expiry of prescribed time limit, in a judicious manner. Deemed approval may be allowed for situations that have low risk involved as well as forspecial cases such as affordable housing.

7. Empower or empanel 'competent professionals' at state/local level to support ULB staff-

It is well established and documented that the urban local bodies in India do not have adequate capacity and expertise to function efficiently.Empanelling 'competent and licensed professionals' to perform certain activities in the approval process where they are competent, thus reducing the work load on ULB staff.

\section{CONCLUSION}

1. The concept of a 'Single window' or 'One stop shop' is widely recognized as an effective tool to ensure speedy approvals.

2. Central single window system should be developed for approvals and that should be visible to home buyers by which they will get status of their sweet home and they can decide in which project they can invest.

3. Use of technology should be introduced to reduce paperwork and personal visits.

4. Streamlining of approval procedures is a need of time as present system is cumbersome and lengthy.

5. The current procedures followed by local Governments, starting from receiving the application to giving the completion certificate, are ridden with a lack of clarity or structure, complexity of design and operation, inefficiency and uncertainty and time/resource consumption.

6. One of the foremost demands of the Real estate industry across the Country is to facilitate fast track and transparent system of project approval procedures.
7. Authority must give permission to developers for construction only after all types of NOCs and approvals.

8. Simultaneously hundreds of projects are in a queue for approval therefore delays are occured.

9. Many times new clauses are not familiar to municipal authority officials so obviously it takes longer time to get approvals. Therefore officials should study new rules and regulations speedily.

10. Sometimes old records are needed for references so delegate of developer or builder may give unofficial fees to authority for quick results.

11. Every refusal and acceptance of approval should be highlighted through respective departments on screen.

12. Delays ought to be mentioned on screen with days, time, exact reason.

13. Because after this only we will have transparent system which boost real estate industry with country economy.

\section{REFERENCES}

[1] K. B. Vaghani, Dr. N. C. Shah and Dr. Krupesh A Chauhan, Impact of Building Byelaws on Housing: A Comparative Study of Development Control Rules of Jaipur and Pune,Institute of Town Planners, India Journal 7 - 2, 34 - 40, April June 2010

[2] Ministry of Housing and Urban Poverty Alleviation (MoHUPA), Report of The Committee of Streamlining Approval Procedures for Real Estate Projects In India, Key Recommendations, Volume I,12 September 2012.

[3] Town and Country planning organization, Government of India, Ministry of Urban Development, Streamlining procedures for clearance of building projects, September 2010.

[4] Report of the Committee on Streamlining Approval Procedures for Real Estate Projects in India,Key recommendations, Volume-I, 12 September 2012

[5] Neeraj Sharma, RakeshAgarwal, Arjun Roy, Grant Thorton, Indian Real Estate Sector Handbook ,2015.

[6] Crisil Research: India Real Estate Overview, March 2010.

[7] NeerajBansal, Indian Real Estate-Opening Doors,KPMG International 2014

[8] KlavsSedlenieks, Corruption in the process of issuing building permits, ISBN 9984-751-38-4

[9] Central Public Works Department, Various Local Approvals and Clearances required 
for large scale project in metro cities, $25^{\text {th }}$ October,2013.

[10] Peer Experience And Reflective Learning (PEARL) Programme. Title of the Reform: Streamlining of Building Plan Approval Process,Pune Municipal Corporation,National Institute of Urban Affairs (NIUA), New Delhi.

[11] RupaliKavilkar, ShwetaPatil, Study of High Rise Residential Buildings in Indian Cities (A Case Study -Pune City), IACSIT International Journal of Engineering and Technology, Vol. 6, No. 1, February 2014.

News Publications and Telemedia Publications,

[12] The Hindu: G. ShyamSundar, Lists mandatory norms for constructing multistoreyed buildings in Tamil Nadu,Published:April 22, 2016, 22:48 IST.

[13] The Indian Express:VishwasWaghmode, Maharashtra: Govt-appointed panel makes high-rise approvals simpler,Published: March 31, 2016, 1:25 am.

[14] CNBC TV 18 Moneycontrol.com:Project delays-deviations and customer woes in real estate.

[15] CNBC Awaaz:Maharashtra RERA penalty related clauses finalized.

[16] Property Plus : RERA to be implemented from 1st May

[17] Z-Business :Batayenge Hum Episode for RERA. Journal with Sl. No. 4525, Journal no. 47088. Indexed in Cross Ref, Index Copernicus (ICV 80.82), NASA, Ads, Researcher Id Thomson Reuters, DOAJ.

Kushal K.Panchariya. "Investigation of Causes of Delay in High Rise Building Project and Remedial Measures Case Study-Pune." International Journal of Engineering Research and Applications (IJERA) 7.7 (2017): 72-77. 